\title{
Understanding the Patterns of Processed Seafood Exports from Sri Lanka: Application of the Gravity Model to Quantify the Determinants
}

\author{
Kariyawasam Pinikahana Gmage Lahiru Sandaruwan ${ }^{*} \oplus$, Suvajit Banerjee ${ }^{2}$ (๑)
}

\author{
${ }^{1}$ Scientist, Socioeconomics and \\ marketing research division of \\ National Aquatic Resources \\ Research and Development \\ Agency, National Aquatic \\ Resources Research and \\ Development Agency (NARA), \\ Craw Island, Mattakkuliya, \\ Colombo 15, Sri Lanka \\ ${ }^{2}$ PhD Scholar, Department \\ of Economics and Politics, \\ VidyaBhavana, VisvaBharati \\ University, Bolpur, Santiniketan, \\ Dist: Birbhum, West Bengal, India \\ * Corresponding Author \\ (kariyawasam.lahiru@gmail.com)
}

Received: 10 July, 2020

Revised: 23 October, 2020

Accepted: 18 November, 2020

Published: 15 December, 2020

How to cite this paper: Sandaruwan, K.P.G.L., \& Banerjee S. (2020). Understanding the patterns of processed seafood exports from Sri Lanka: Application of the Gravity Model to quantify the determinants. Quest Journal of Management and Social Sciences, 2(2), 181-193.

Copyright (C) 2020 by authors and Quest Journal of Management and Social Sciences.

This work is licensed under a Creative Commons Attribution-Non Commercial-No Derivatives 4.0 International License. https://creativecommons.org/ licenses/by-nc-nd/4.0/

\begin{abstract}
Background: Grabbing the emerging opportunities, from the escalated global demand for processed seafood due to the modern lifestyle induced changes in the food consumption pattern of the households, could be a great advantage for Sri Lanka to increase its international trade activity. This could also help Sri Lanka earn more revenues by adding value through the processing of the raw fish and through that eliminating high postharvest loss during the peak seasons.
\end{abstract}

Objective: This research intends to study the patterns of global and Sri Lankan trade in the seafood sector and identifies the determinants in terms of their impacts on the processed seafood export.

Methods: The Gravity Model was run with the secondary data collected from UNCOMTRADE. The panel data include seafood export data of Sri Lanka from 2001 to 2014 with 107 countries and 144 products.

Results: However, only one \% of the Sri Lankan processed seafood adds value to the ultra-processed level, so it cannot reach the maximum potentials in job creation and profitability. This study has found that the elasticity values of tariff and non-tariff measures (NTMs) are higher for the processed seafood than the unprocessed seafood. This way, the processed seafood becomes more vulnerable to changes in tariff and NTMs than the unprocessed seafood.

Conclusions: The conversion of unprocessed seafood into processed seafood can improve the export revenue for Sri Lanka but these conversions are increasing the vulnerability of seafood exports due to the stringent market barriers.

Keywords: Processed seafood; non-tariff measures; gravity model; export performance; Sri Lanka

JEL Classification: F12 and F14 


\section{Introduction}

The processed seafood market is recognised as one of the most vibrant segments of international trade particularly due to two principal factors (Sandaruwan et al. 2020, Shamshak et al., 2019; Maurseth and Medin, 2017). Firstly, the global demand for seafood products increased as a combined impact of both the increasing annual per capita fish consumption, which was around $9.0 \mathrm{kgs}$ in 1961 to 20.5 $\mathrm{kgs}$ in 2017, and the ever-increasing total fish-consuming population (FAO, 2018). Secondly, modern lifestyle-induced food habits that have grown in recent times around the world changed the behaviour of the people in their food consumption and preparation practices (Ying 2020, Baker and Friel, 2016 and Smith et al. 2013). Smith et al. (2013), in his study, recorded that the processed food ${ }^{1}$ consumption $^{-}$ has increased in the household level in the USA due to the fact that the working families in modern society are dedicating much lesser amount of time for food preparations than before. A similar pattern is observed by Baker and Friel (2016) in the case of Asia where a clear transformation towards ultraprocessed food consumption is indicated. As far as the processing of seafood products is concerned, the value-addition during the processing is eventually becoming one of the most important activities to raise the profitability of the fishery industry, since this industry is becoming increasingly competitive both in local and in global markets (Sharif and Zahid, 2018; Zhang Tveterås, 2019 and Fatema 2020). The seafood processing industry report of the UK (elaborates on the economic importance of the fish processing industry. According to this report, the fish processing activities are capable of adding 30\% of extra value to one unit of raw fish. As a result, the fishery industry can benefit from at least $10 \%$ increase in the annual average operational profit while generating $18 \%$ of more labour opportunities than the raw fish production activities (Noble, 2017).

Because seafood is a highly perishable food item, it is essential to increase its shelf-life, improve its product quality and create more product varieties through processing activities for making them exportable into the international market. However, access to these processed seafood in the foreign markets is highly constrained through market access barriers such as tariff and non-tariff measures. While the tariff rates of the fisheries sector were very high until 1993, the member countries of General Agreement on Tariff and Trade (GATT) conducted multilateral trade negotiations round in Uruguay and agreed to reduce average tariff rates for fish all over the world (Melchior, 2006). But these lower tariff rates are not equally enforced for all seafood items, because the processed or value-added fish products get much higher duty rates than the unprocessed fish (FAO, 2018). Instead, the seafood tariffs slightly increased in 2018 and 2019 because of the trade war between the USA and China, when they increased their tariff rates on bilateral trade of processed seafood by $10 \%$ to $25 \%$ (FAO, 2019). On the other hand, the benefits from the international agreements on the reduction of tariff measures are offset through the expansion of the scope of Non-Tariff Measures (hereafter mentioned as the NTMs). ${ }^{2}$ The products of seafood are more intensively affected by NTMs than products belonging to nonfish sectors. The United Nations Industrial Development Organization (UNIDO, 2011) conducted a comprehensive analysis of the border rejection data of the European Union and the United States (US) from 2002 to 2008 for the agricultural products and found that the second-highest number of rejection and detention in quantity terms was reported for fish imports, and even in value terms, fish items found as the highly rejected food category. Fugazza (2017) found that among all the NTM types, Sanitary and Phytosanitary measures (SPSs) and Technical Barriers to Trade (TBTs) are frequently applied to seafood products, so that the average numbers of TBTs applied on fisheries products were found to be

\footnotetext{
${ }^{1}$ Food processing may be defined as a value-added method used to transform inedible raw items into edible food or to transform food into different food varieties for the consumption of humans or animals by either in the house or in the food processing enterprises (FAO, 2004; Singh 2015).

2 The United Nations Conference on Trade and Development (UNCTAD, 2013) has defined the NTMs as any policy other than ordinary customs tariff that can potentially have an economic effect on international trade in goods, changing quantities traded or prices or both.
} 


\section{5 times higher than the manufactured products.}

The Sustainable Development Goals, among other initiatives, urged the world to eliminate poverty (SDG 14), which is inherited in the fisheries sector of the developing world. The oversupply of fish in the peak seasons drops the price in the local markets. The rapidly perishable nature of the fish and unavailability or insufficiency of the preservation facilities compel the fishermen to sell their products at lower prices which leads to escalating postharvest loss during these peak seasons. The annual postharvest loss of fish production of Sri Lanka was recorded as high as $40 \%$, which is substantially higher than the entire fisheries industry of many countries (Daluwatte and Sivakumar, 2018). The best way to eliminate post-harvest loss and income fluctuation of poor fishermen is to enhance the production of processed fish in the country (Murugan and Sivagnanam, 2018).

As an island of the Indian Ocean, Sri Lanka has a great potential in the processed seafood industry to access foreign markets. Now, successfully penetrating the highly competitive foreign markets requires a substantial amount of information on the current market conditions, trends and market access barriers. In this regard, this study, on one hand, intends to make a comprehensive inspection of the pattern and composition of seafood exports from Sri Lanka relative to that of the world seafood trade. At the same time, it tries to understand how trade barriers may impact on the processed seafood export in case of Sri Lanka.

Studies to analyse of impacts of NTMs exclusively on Sri Lankan fish and seafood export is rarely attempted so far (Sandaruwan and Weerasooriya 2019). Asian Development Bank conducted a recent study on Sri Lanka's potential exports and the impact of nontariff barriers (NTBs) on Sri Lankan trade (ADB, 2019). However, this research covered the entire export basket of Sri Lanka and only analysed a few international regulations that are directly affecting the fish exports. In an earlier attempt, a gravity model-based analysis between Sri Lanka and other SAARC countries were done by Rahapakse and Arunatilake. They also analysed a bundle of different export products including the fish and found that the NTBs generated negative impacts on the trade relationship between Sri Lanka and other SAARC countries. However, it is important to note that the paper does not give sufficient information on seafood exports of Sri Lanka. Therefore, there is a knowledge gap in that study which makes it impossible to fully understand the seafood export patterns of Sri Lanka and the effects of trade regulation measures specifically on seafood exports.

This study is structured as follows. In the next section, the recent ban of European Union (EU) on seafood exports from Sri Lanka is explained to establish the relevance of this study. The empirical model and the data collection issues are explained in the third and fourth sections respectively. The fifth section elaborates on the results. Finally, in the sixth section, this study concludes the article with some important takeaways.

\section{Review of Literature}

\section{Import-Ban by the EU and Sri Lankan Seafood Export}

Sri Lanka was notified under the Illegal, Unreported and Unregulated (IUU) Fishing legislation mechanism by the EU in 2010. Among the legislations enforced to mitigate IUU fishing, the TBT is considered the most effective policy approach. In order to comply with the TBT, the exporting country must issue Catch Certification/Certificate (CC), so those producers can prove their permission to catch the fish. To strengthen the implementation of such a TBT measure, the European Union installed a strong inspection framework through official networks and leveraging technology at airports, harbors and all other entry points. If the exporters fail to submit a valid CC continuously or fail to comply with other international laws, like the United Nations Convention on the Law of the Sea or the United Nations Fish Stocks Agreement, etc., they may be 'carded', which means that they could ultimately face sanctions to export their fish to the EU market. 
The EU suggested Sri Lanka take corrective actions to resolve the shortcomings such as the lack of dialogues and actions to address deficiencies in monitoring, controlling and surveillance of the fishery activities. Since the Sri Lankan Government failed to achieve significant improvements, a yellow card was issued to Sri Lanka, as well as for seven other countries on 15th of November 2012 (European Commission, 2012). Then Sri Lanka has been given a reasonable time to respond and take measures to rectify the situation. However, the EU assessment in 2014 found that Sri Lanka has not sufficiently addressed the shortcomings. These shortcomings are mentioned at the issuance of the yellow card. As a result, the European Commission enforced a ban on the fishery products caught by Sri Lankan vessels being imported into the European Union.In order to avoid disrupting commercial contracts, the full trade measures came into force in mid-January 2015 (European Commission, 2016a). Since then, the Sri Lankan Government initiated many prompt and prudent measures to comply with the requirement stipulated by the EU. As a result of significant improvements to control IUU fishing, the ban was lifted by the EU from the Sri Lankan seafood export on 12thof April 2016 (European Commission, 2016b). The conditions rose by the EU and the actions taken by the Government of Sri Lanka are represented in the form of Table 1 below.

Table 1. Initiatives by Sri Lanka to remove the fish import ban by the EU

The EU Conditions The Sri Lankan Responses

Take measures to control destructive fishing gears.

Install a vessel monitoring system

Control poaching from foreign sea territories

Recruit official observers to fishing boats at sea

Maintain a logbook in the boat

Increase IOTC compliance rate

Continuous sampling fish catch
Banning destructive fishing gears, penalties for uses, regulation of craft inspection at the harbor and sea were gazetted.

Fixed transponders to 1,500 boats and established vessel monitoring stations at the end of 2016, and licences for high seas have been only issued for crafts with vessel monitoring systems.

A penalty of a minimum of 1.5 million Rupees for poachers and cancellation of the fishing licences

Recruit observers to cover $25 \%$ of large-scale vessels $(>18 \mathrm{~m})$

Submission of a logbook by every fishing boat compulsory to enter fisheries harbours.

The compliance rate exceeded $80 \%$ in 2017

National Aquatic Resources Research and Development Agency continues projects to study fish catch

Source: Prepared by the authors based on the Department of fisheries and aquatic resources (2015).

\section{The Empirical Model}

This study applied a modified form of gravity model $^{3}$ as the major quantitative technique for the bilateral trade analysis on seafood products from a Sri Lankan perspective. The gravity modelbased trade analysis was initially performed in international economic researches without any robust theoretical background in Economics (Linders and Groot, 2006). As a turning-point, Bergstrand (1985; 1989) elaborated on the gravity model from an authentic macroeconomic sense and incorporated both demand- and the supply- side factors. Hereafter, Anderson and van-Wincoop, (2003) mitigated the

\footnotetext{
${ }^{3}$ Newton's equation of gravity motivated Tinbergen (1962) to introduce gravity model into the analysis of international trade.
} 
omitted variable bias $^{4}$ through the introduction of multilateral resistance terms, so that this model becomes a popular tool for empirical exercises on international trade. There has been frequent attempts to apply this gravity model in the analysis of tariffs and NTMs as the barriers for the international trade flows and its implications on other macroeconomic features (Thuong, 2017; Rindayati and Kristriana 2018; Santeramo and Lamonaca 2019, Timini and Conesa 2019).

Now, the log-linearized and non-linear transformed models of panel data processing (such as the OLS, the random and the fixed effects models) may generate biased estimations due to statistical problems of heteroscedasticity, presence of too many zero trade values and over-dispersion of the data (Rindayati and Kristrian, 2018). To overcome these statistical issues, Silva and Tenreyro $(2006 ; 2011)$ suggested applying Poisson Pseudo Maximum Likelihood (PPML) estimator which is found robust against the problem of heteroscedasticity by creating a variance proportionally to the mean. The PPML is also found to well-perform in handling zero trade values (Silva and Tenreyr, 2011). The PPML estimation for gravity analysis is applied in many recent studies for its advantages over other similar estimators (Braha et al., 2017; Wood et al., 2017; Ehrich and Mangelsdorf; 2018). The empirical exercise of this study is based on the following gravity equation of trade as shown in equation (1).

$$
\ln X_{i j t}^{k}=\beta_{1} \ln G D P_{i t}+\beta_{2} \ln G D P_{j t}+\beta_{3} \ln D I S_{i j}+\beta_{4} \ln \left(1+T_{i j t}^{k}\right)+\beta_{5} D N T M^{k}{ }_{i j t}+\beta_{3} \ln P_{i j}+\beta_{3} \ln E_{j t}+\varepsilon_{i j t}^{k}
$$

where $X_{i j t}^{k}$ is the export value of product k to the $i^{-t h}$ importing country from Sri Lanka at time $t$, GDP ${ }_{i t}$ is the gross domestic product of $i_{-}^{\text {th }}$ import country at time $t, G D P_{j t}$ is the gross domestic product of Sri Lanka at time $t, D I S_{i j}$ is the distance between the capital of the $i_{-}{ }^{\text {th }}$ import country and capital of Sri Lanka, $T_{i j t}^{k}$ is the tariff rate imposed by country $i$ for exported product $k$ from Sri Lanka, DNTM ${ }_{i j t}^{k}$ is the dummy for NTMs which equals one if country $i$ imposed NTM on the exported product $k$ from Sri Lanka and zero otherwise, and $\varepsilon^{k}$ ijt is the error term. A dummy variable is used as ' $P$ ' to recognise processed seafood. For the robustness test, the same equation is used with an additional dummy variable to understand the effect of the EU ban. Here, ' $E$ ' represents the EU ban on Sri Lankan seafood items during the banned period (2014-2016).

Data is arranged into a panel structure, consisting of 17 year time periods across 107 countries. The descriptive statistics of all the variables are obtained and summarized. For the zero values in the export data, a small constant value (1 US\$) is added to substitute the zero values in trade. To overcome the zero tariff and NTB issues tariff and NTB variables are modified as Tariff rate +1 and NTB +1 (Thuong, 2017). All the variables are converted into a natural logarithm as per the gravity model equation before carrying out further analysis.

\section{Research Method}

Distinguishing the processed foods from unprocessed food is the most critical task for any international trade studies on food. Both the Harmonised Coding System (HS) and the Standard International Trade Commodity system (SITC) use different classification methods. The HS code system categorized the seafood products into species level and in the finest forms of a processed level. But in some seafood categories, SITC provides more details about processed food (crustacean and mollusc products). The relationship between the HS and the SITC classification is done through the correspondent table of the UNCTAD (United Nation Trade Statistics Knowledge Database, 2017). However, neither the HS nor the SITC systems have clearly separated the processed foods from the different layers of unprocessed foods.

\footnotetext{
${ }^{4}$ When a model excludes important independent variable(s), omitted variable bias error may occur. Anderson and van-Wincoop suggested multiple important trade barriers to incorporate into a gravity model to resolve the omitted variable bias issue. It is difficult to find out all the trade barriers among all trade partners, hence they have suggested statistically estimated ratios to represent the multilateral trade resistance (Head and Mayer, 2014).
} 
Natale et al. (2015) have identified three major processing categories in seafood of HS 6 level, as the preservation (Live fresh, chilled fresh, frozen, dried, smoked, salted, pasteurised, prepared preserved), the preparation (cut fillets, whole, by-products, extraction of oil and other nutrition) and the packing (bottling, warping, canning etc.). The fifth revision of the Broad Economic Classification (BEC) clearly classified the products as primary and processed (United Nations, 2016). According to this classification, the primary products, as live, fresh and chill seafood are defined as the unprocessed; they are original and natural products without any significant changes. The processed products, on the other hand, include all the other products that do not belong to the primary products (Food and agriculture organization of the United Nations, 2008). Although, this dichotomous classification is easy to use in statistical analysis, it provides very little information about the level of value added to the products. For instance, more values are added in the ultra-processed foods than the minimally processed products, so that the value chains of ultra-processed food products provide more job opportunities and better scopes for revenue generation for the entire economy. To address this issue of the difference in classification of the processing activities, nutritionists generally rely on the NOVA food classification system, which is originally developed in Brazil. NOVA has four groups as unprocessed or minimally processed, processed culinary ingredients, processed foods and ultra-processed foods (Sande, 2019).

However, this study used both the HS and the SITC classification systems and followed the BEC based criteria more conveniently to separate processed foods from unprocessed foods. The fish export value data of Sri Lanka is collected from 2001 to 2017 from the UN COMTRADE and through the trade-map of the UNCTAD. HS 03 is the main commodity for this study. The real Gross Domestic Product (GDP at constant 2010) and population data are collected from the World Development Indicators (WDI) database while the bilateral distance between the capital city of Sri Lanka and that of the importing countries are taken from the Institute for Research on the International Economy (CEPII). The most favoured nation (MFN) tariffs rates at the HS 6-digit level are collected from the World Integrated Trade Solution (WITS) database while the numbers of NTMs imposed by the importing countries are gathered from the World Trade Organization (WTO) and Trade Analysis Information System (TRAINS) of the UNCTAD. The export values are measured in nominal prices because deflating the values of export using price indices would not adequately capture the unobserved multilateral resistance terms, and could produce misleading results (Shepherd, 2016).

\section{Data Analysis and Result}

\section{Sri Lankan Seafood Export Compared to World Seafood Export}

The annual contribution in the world seafood market from Sri Lanka has been around 0.3\% during the period 2001-2017. Table 2 includes the major seafood export categories under three principal classification systems, namely the BEC, the HS and the NOVA, in terms of their percentage contributions in the total seafood exports for Sri Lanka and for the world respectively. According to the BEC classification, the percentage of processed seafood export from Sri Lanka and that of globally is found almost similar (for Sri Lanka 60.62\%and globally 63.04\%). The HS4 classification does not categorise processed products in a straightforward way, but their fresh fish category, consisting of live and chilled form, implicitly denotes that the rest of the products belongs to the processed group. While according to the HS6 classification, the global seafood export was found to be composed of fresh seafood of $36.96 \%$, followed by frozen fish of $21.16 \%$, fish cured (dried, salted, in brine, fermented smoked) of $15.82 \%$, ready to eat instant seafood of $22.75 \%$ and other products of $3.31 \%$, at an average for the period 2001 to 2017. According to HS classification, the composition of Sri Lankan exports basket is as follows, fresh fish of $39.38 \%$, followed by frozen fish of $52.82 \%$, fish cured (dried, salted, in brine, fermented smoked) of $6.47 \%$, ready to eat instant seafood of $0.58 \%$ and other products of $0.75 \%$. 
However, the classification of NOVA has portrayed a completely different picture than the previous two classifications. According to the NOVA classification, Sri Lankan seafood exports were found to exist far behind the global seafood exports in terms of their level of value additions to the raw fish resources. Sri Lanka exported $0.58 \%$ of ultra-processed seafood in the total seafood exports during 2001-2017, while globally this percentage was around $22.75 \%$. Figure 1 portrays the major varieties of processed seafood exports from Sri Lanka during the period 2001-2017. This can be clearly observed from the figure that the maximum proportion of the Sri Lankan processed seafood consists of minimally processed chilled and frozen products which count to almost $90 \%$ of the total processed seafood. Therefore, the majority of processed seafood of Sri Lanka consists of less value-added and minimally processed seafood category. Therefore, Sri Lanka, according to this NOVA classification, has an immense scope to add more value to the seafood export sector and increase its commercial competitiveness. Besides, generating revenues through increased levels of value addition in the fish products are more viable as a trading strategy than to increase these revenues through increasing fish catch from the coastal and the deep sea activities in the face of depleting global fish stocks.

Table 2: Seafood exports for Sri Lanka vis-à-vis the world under different classifications (In Percentage)

\begin{tabular}{|c|c|c|c|c|c|c|c|c|c|}
\hline \multicolumn{3}{|c|}{ BEC } & \multicolumn{4}{|c|}{ HS } & \multicolumn{3}{|c|}{ NOVA } \\
\hline Category & $\begin{array}{c}\text { Sri } \\
\text { Lanka }\end{array}$ & World & $\begin{array}{l}\text { HS4 } \\
\text { Code }\end{array}$ & Category & $\begin{array}{c}\text { Sri } \\
\text { Lanka }\end{array}$ & World & Category & $\begin{array}{c}\text { Sri } \\
\text { Lanka }\end{array}$ & World \\
\hline \multirow{5}{*}{ Unprocessed } & \multirow{5}{*}{39.38} & \multirow{5}{*}{36.96} & 0301 & Live fish & 0.21 & 2.53 & \multirow{4}{*}{$\begin{array}{l}\text { Unprocessed or } \\
\text { minimally processed }\end{array}$} & \multirow{4}{*}{97.93} & \multirow{4}{*}{71.55} \\
\hline & & & 0302 & Chilled fish & 39.17 & 34.43 & & & \\
\hline & & & 0303 & Frozen fin fish & 52.82 & 21.16 & & & \\
\hline & & & 0304 & $\begin{array}{l}\text { Dried, smoked, } \\
\text { cook }\end{array}$ & 5.73 & 13.43 & & & \\
\hline & & & 0305 & Salted or in brine & 0.74 & 2.39 & $\begin{array}{l}\text { Processed culinary } \\
\text { ingredients }\end{array}$ & 0.74 & 2.39 \\
\hline \multirow{4}{*}{ Processed } & \multirow{4}{*}{60.62} & \multirow{4}{*}{63.04} & 0306 & $\begin{array}{l}\text { Flour, meal, } \\
\text { pellets }\end{array}$ & 0.71 & 1.8 & \multirow{3}{*}{ Processed foods } & \multirow{3}{*}{0.75} & \multirow{3}{*}{3.31} \\
\hline & & & 0307 & Fish oil & 0.03 & 1.19 & & & \\
\hline & & & 0308 & Fish juice & 0.01 & 0.32 & & & \\
\hline & & & 0309 & $\begin{array}{l}\text { Prepared/ Ready } \\
\text { to eat }\end{array}$ & 0.58 & 22.75 & Ultra-processed food & 0.58 & 22.75 \\
\hline
\end{tabular}

Source: Author prepared based on UN COMTARDE data 2001 - 2017.

Figure 1: The varieties of processed seafood exports from Sri Lanka

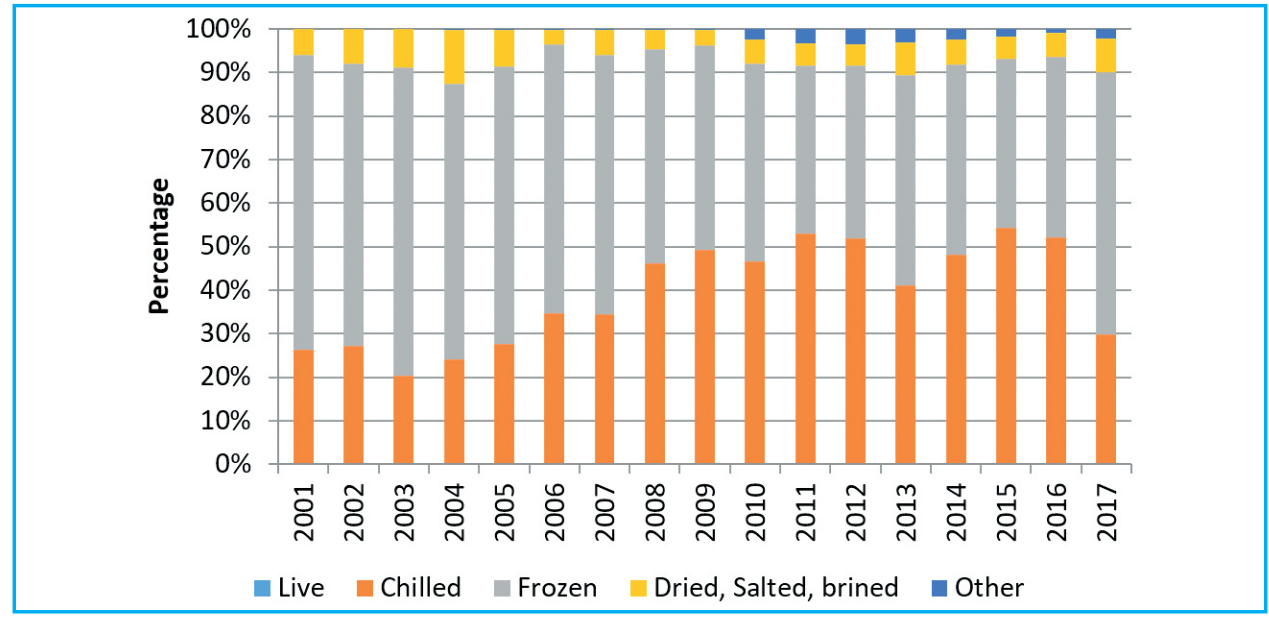




\section{Trends of Sri Lankan Processed Seafood export}

Figure 2 shows the revenues generated from Sri Lanka's processed seafood exports, unprocessed seafood exports and total seafood exports for the period 2001-2017. The long-run compounding growth rate of Sri Lanka's total fish exports has been on the rise at $6.27 \%$ during 2001-2017. The drop in total seafood export was experienced in 2005 due to the tsunami disaster at the end of 2004. The tsunami highly impacted the fresh seafood exports than the processed seafood because a large amount of fresh seafood comes from the coastal fishery. For the tsunami, the coastal fishery industry experienced a greater shock than the deep-sea fishery. Assistance from the government and foreign funding helped revive these fishery sectors so that the total fish export steeply grew after 2005. Again, after 2008, the growth rate of revenues from the fish export declined because of the reduced international demand as a result of the global economic slowdown from the subprime mortgage crisis in the USA and the removal of the GSP tariff concessions by the EU. In recent times, Sri Lankan seafood export experienced another big blow during 2014-2016 due to the EU ban under IUU fishing. This impact was more severe on the processed seafood export, as can be observed from Figure 2, with the sudden fall in the blue line, whereas the unprocessed seafood export remained relatively steady. This is because the EU was the largest import market of processed seafood for Sri Lanka (Beukers, 2012). Consequently, the seafood processing units reduced their production of high value-added seafood commodities and started exporting raw items to the re-exporting countries such as the Maldives, Thailand and Vietnam. Therefore, this is clear from this analysis and the graph that fresh seafood has more resilience because of comparatively lower prices and a larger number of buyers than processed seafood.

\section{Figure 2: Evolution of fish exports of Sri Lanka}

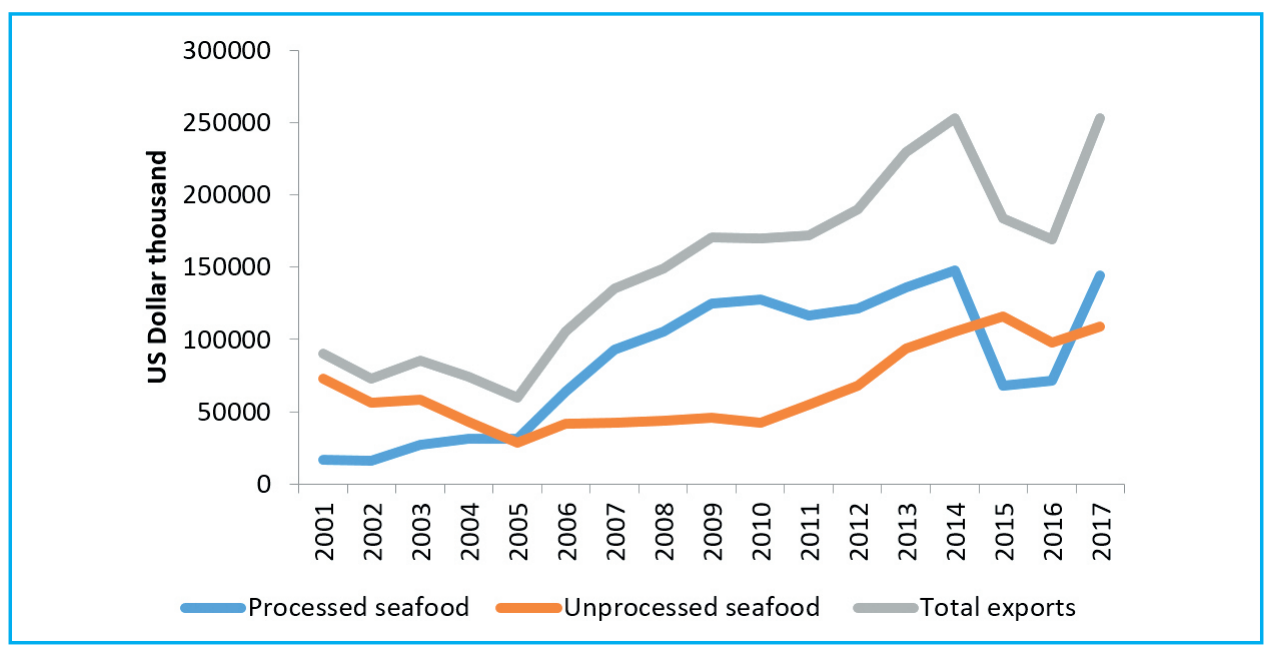

\section{Determinants of processed seafood export of Sri Lanka}

The number of NTMs imposed to regulate the seafood export from Sri Lanka trebled during the last two decades after the GATT obligation for a phased reduction in tariff rates. As far as the composition of the NTMs is concerned, the SPSs were applied more frequently than the TBTs and the other NTMs. According to this analysis, the percentage of SPSs, TBTs and other NTMs were 57\%, 28\% and $15 \%$ respectively from 2001 to 2017 . While studying the impacts of these NTMs separately on the processed and the un-processed seafood exports, it is found that at an average (both in-country and in timewise average) 19 NTMs were enforced on the unprocessed seafood and 24 NTMs were enforced on the processed seafood. During 2001-2017, the global average tariff rates against Sri Lankan seafood export declined at the rate of in $2.18 \%$ annually. Significantly high tariff rates were found enforced 
on processed seafood (With mean 19\%, standard deviation 7) than unprocessed seafood (With mean $9 \%$, standard deviation 5). Developing countries were found imposing higher average tariff rates than developed countries on seafood export of Sri Lanka $(t=-2.876 \mathrm{p}=0.02)$. The mean tariff rates imposed by the developing and the developed countries on the processed seafood export of Sri Lanka were found to be $23 \%$ (with standard deviation 9) and 17\% (with a standard deviation of 10).

The gravity model estimation results are reported in Table 3 below. Table 3 includes seven columns with the values of the coefficients from seven estimations. This study runs three models with the original database which consists of all the products. This original database of all the products is split into two sub-databases, the processed seafood database and the unprocessed seafood database. Column (I) in Table 3 indicates the gravity model of the PPML estimator without any binary variable. With the same original database, the results after introducing a dummy variable for processed food are obtained along the column (II). The last column of all products (III) consists of the results of the original model including a dummy for the processed food and a dummy variable for the EU ban. Column (IV) and (V) bears the estimation of only the processed food, while (IV) brings the result without including any dummy variable to capture the effect of the EU ban and (V) brings the result by including such a dummy variable. In a similar way, column (VI) and column (VII) exclude and include the EU dummy in case of unprocessed seafood respectively.

According to the results from the PPML estimation, among the factors that are significantly affecting the export of Sri Lankan seafood, are both the GDPs of the importing countries and of Sri Lanka, the distances of the importing countries, the tariff rates of the importing countries, and the NTMs imposed by the importing countries. The value of the coefficient of GDP of Sri Lanka was positive and much similar in all the models as shown in (I)-(VII) columns. In the case of the GDP of the importer, however, this study found a clear difference for the processed and unprocessed seafood models. When the income of the importer increases they tend to buy more processed seafood. Similarly, with the decreasing income of the importing countries, they drastically reduced the consumption of processed seafood. The unprocessed seafood segment found was more inelastic for changes to the GDP of importers. This may be due to the lesser amount of value addition in the case of raw seafood, which bears a minimum price impact. The distance factor was found negative for all estimations except for the unprocessed seafood models because there are stronger negative coefficients than the processed seafood. The reason behind this finding may be due to the fact that the unprocessed seafood has a small shell-life so there is a greater risk in shipping these products to a further distance. Therefore, processed seafood is imported by the countries which are geographically far away countries while unprocessed seafood is imported by the nearer countries. The tariff was found to have a very high impact on the seafood trade for all the estimations. The coefficient of the tariff variable was found to be negative for all the estimations and particularly among them was the estimation of processed seafood. It has the strongest negative value, implying that the processed seafood is more sensitive to tariff than unprocessed foods. From columns (ii) and (iii), where the dummy variable is included for processed foods, this can be interpreted that with increased processed seafood in the total seafood export basket there is a greater tendency to increase the value of exports.

The coefficients of the NTMs in all the models were found negative, implying that imposition of the NTMs discourages exports of all types of seafood. However, these coefficients for the processed seafood were found to be more elastic than unprocessed seafood. The economic substance is that, when there is an increase in the NTMs for the processed foods the production cost increases significantly higher in a way that the exporters sell the seafood in raw form to other countries that can import these raw seafood and then process to re-export. Another interesting finding is that when comparing the coefficients of the EU ban on the processed seafood and the unprocessed seafood, the export value of processed seafood declines (-0.99), whereas, that of unprocessed seafood (0.69) increases. And as a result, the aggregated impact during the EU ban period found the total export value of seafood 
to decrease (-0.29). EU is the major buyer for processed seafood of Sri Lanka, when they stopped purchasing processed food the export declined steeply but Sri Lanka managed to find some new export market for raw fish, hence fresh seafood does not decline as vigorously as processed seafood.

Table 3: Results of the PPML Regression to estimate the Gravity Model

\begin{tabular}{|c|c|c|c|c|c|c|c|}
\hline & \multicolumn{3}{|c|}{ All products } & \multicolumn{2}{|c|}{ Processed } & \multicolumn{2}{|c|}{ Unprocessed } \\
\hline & $\mathrm{i}$ & ii & iii & iv & $\mathrm{v}$ & vi & vii \\
\hline \multirow[t]{2}{*}{ GDP Of Sri Lanka } & $0.60 * *$ & $.60 * * *$ & $0.58 * * *$ & $.62 * * *$ & $0.61 * *$ & $0.56 * * *$ & $0.57 * * *$ \\
\hline & $(0.04)$ & $(.041)$ & $(0.04)$ & $(.027)$ & $(0.03)$ & $(0.09)$ & $(0.09)$ \\
\hline \multirow[t]{2}{*}{ GDP of importer } & $1.03 * *$ & $1.03 * *$ & $1.14 * * *$ & $1.79 * *$ & $1.96 * *$ & $0.24 *$ & $0.29 *$ \\
\hline & $(0.27)$ & $(.26)$ & $(0.28)$ & $(.21)$ & $(0.22)$ & $(0.46)$ & $(0.48)$ \\
\hline \multirow[t]{2}{*}{ Distance } & $-0.36 * *$ & $-.35 * *$ & $-0.30 * *$ & $-.28 * *$ & $-0.34 * *$ & $-1.57 * *$ & $-1.57 * *$ \\
\hline & $(0.12)$ & $(.12)$ & $(0.13)$ & $(.09)$ & $(0.10)$ & $(0.25)$ & $(0.25)$ \\
\hline \multirow[t]{2}{*}{ Tariff } & $-1.17 * *$ & $-1.15^{* *}$ & $-1.70 * *$ & $-3.20 * *$ & $-3.54 * *$ & $-1.98 * *$ & $-1.96 * *$ \\
\hline & $(0.80)$ & $(.78)$ & $(0.81)$ & (.69) & $(0.70)$ & $(0.52)$ & $(0.55)$ \\
\hline \multirow[t]{2}{*}{ NTM } & $-0.47 * *$ & $-.46 * *$ & $-0.45 * *$ & $-.91 * * *$ & $-0.91 * *$ & $-0.20 *$ & $-0.17 *$ \\
\hline & $(0.18)$ & $(.18)$ & $(0.18)$ & $(.21)$ & $(0.21)$ & $(0.22)$ & $(0.22)$ \\
\hline \multirow[t]{2}{*}{ Processed food } & & $.13 * * *$ & $0.10 * * *$ & & & & \\
\hline & & $(.10)$ & $(.15)$ & & & & \\
\hline \multirow[t]{2}{*}{ EU Ban } & & & $-0.29 * *$ & & $-0.99 * *$ & & $0.69 * * *$ \\
\hline & & & $(0.24)$ & & $(0.26)$ & & $(0.36)$ \\
\hline \multirow[t]{2}{*}{ Constant } & $1.16 * *$ & $1.09 *$ & $0.93 * *$ & $-.39 *$ & $-0.74 *$ & $2.72 * * *$ & $2.60 * * *$ \\
\hline & $(0.49)$ & $(.47)$ & $(0.52)$ & $(.39)$ & $(0.42)$ & $(0.82)$ & $(0.85)$ \\
\hline $\begin{array}{l}\text { Number of } \\
\text { observation }\end{array}$ & 26,093 & 26,093 & 26,093 & 15,684 & 15,684 & 10,409 & 10,409 \\
\hline Log likelihood & $-76,621$ & $-76,577$ & $-76,405$ & $-43,416$ & $-43,392$ & $-29,324$ & $-29,323$ \\
\hline
\end{tabular}

Note: '*', ‘**', ‘***' indicates significance level at $1 \%, 5 \%$ and $10 \%$ respectively. Coefficients with robust standard errors are shown in the parenthesis.

The study conducted few diagnostic tests to verify the robustness of the findings by checking the statistical assumptions on no multicollinearity, no serial correlation of the error and stationary, separately for the three databases of the total products, the unprocessed products and the processed products. Multicollinearity was tested through the calculation of the variance inflation factor (VIF) and the values were found to be between 2.5 to 10 within the acceptable limits (Vatcheva et al., 2016). The Serial correlation was tested with the Durbin Watson statistic and the test values for all products, the processed and the unprocessed databases were found as $1.56,1.83$ and 1.78 respectively. Since all the calculated values are much closer to 2 , it can be concluded that there is no first-order autocorrelation in all three databases. To avoid regression results to be spurious, stationary condition of the variables are also assessed using panel unit root tests namely; Levin, Lin and Chu (Levin et al., 2002). The 'p' values of this test for all the variables in three databases were found to be very close and less than 0.05 , which reveals that all the variables in natural $\log$ form are stationary (i.e. the null hypothesis that the data has a unit root found rejected). Table 4 shows the outcomes of these diagnostic tests. 
Table 4. Diagnostic tests

\begin{tabular}{cccc}
\hline $\begin{array}{c}\text { Statistical } \\
\text { assumption }\end{array}$ & Test & Test Statistic & Conclusion of the test \\
\hline Multicolinearity & $\begin{array}{c}\text { variance inflation factor } \\
\text { (VIF) }\end{array}$ & $\begin{array}{c}\text { values found between 2.5 } \\
\text { to } 10\end{array}$ & No Multicolinearity \\
Autocorrelation & Durbin-Watson t-Statistic & Values laid between 1.5 & No autocorrelation \\
Stationary & Levin, Lin and Chu & All the "p" values less & Variables are stationary \\
& Panel Unit Root Test & than 0.05 & \\
\hline
\end{tabular}

Source: Authors' Calculations

\section{Conclusion and Recommendations}

This study compares the trade performance of the processed seafood and the unprocessed seafood of Sri Lanka in terms of a trade ban imposed by the EU using a Gravity model-based Econometric analysis. Although two-thirds of the Sri Lankan fish export basket consists of the processed seafood, the majority of them are minimally or moderately processed seafood and only $1 \%$ adds value up to the ultra-processed level. Despite fluctuations at various times due to different external shocks, the Sri Lankan processed seafood exports were able to maintain steady growth with a comparative advantage in the world market from 2001 to 2017. Sri Lanka, as analysed in this study, shows a higher potential to add more value to its seafood resources and expand the production of ultra-processed seafood. However, access to the international export market for processed seafood from Sri Lanka is more constrained due to non-tariff and tariff regulated market barriers, than unprocessed seafood. The tariff rate is the more critical determinant than the GDP of the importer, i.e. the GDP of Sri Lanka, the distance to the export destination and the NTMs for seafood exports. This addressed that the elasticity of the tariff and NTMs are substantially higher for the processed seafood than for the unprocessed seafood.This in turn implies that the processed seafood is more vulnerable to the imposition of tariff and NTMs as compared to unprocessed seafood. The EU fish import ban impacted processed seafood more negatively than unprocessed seafood. In a nutshell, from this Gravity analysis, this can be concluded that by promoting the unprocessed seafood to the processed seafood, Sri Lanka may improve the export revenue capacity but these promotional activities with food processing may increase the vulnerability of seafood exports for stringent market barriers.

This study suggests that the Sri Lankan government should increase initiatives to comply with international laws and agreements to reduce the possibility of future disruptions from the sudden imposition of regulatory measures by the import partner countries, especially those who are the biggest export destinations of Sri Lankan processed seafood exports. Besides, a diversification of the direction of processed seafood export could also be helpful to ensure steady and uninterrupted revenues from the foreign market of Sri Lankan seafood. In this regard, the regional and bilateral trade agreements may reduce the burden of tariff and NTMs in the seafood industry. It could also be encouraging for the stakeholders of the Sri Lankan fishery industries to promote more value addition activities on the unprocessed seafood.

\section{Conflict of Interest}

No conflict of interest exists while preparing this article. 


\section{References}

Anderson, J. E. \& Wincoop, E.V. (2003). Gravity with gravitas: A solution to the border puzzle. American Economic Review, 93(1), 170-192.

Asian Development Bank, (2019). Potential exports and nontariff barriers to trade Sri Lanka national study. $A D B$ Publication Metro Manila, Philippines 14(1), 38-45.

Baker P., \& Friel S. (2016). Food systems transformations, ultra-processed food markets and the nutrition transition in Asia. Globalization and Health, 12(1), 123-137 doi:10.1186/s12992-016-0223-3

Bergstrand, J.H. (1985). The gravity equation in international trade: Some microeconomic foundations and empirical evidence. The Review of Economics and Statistics, 67, 474-81.

Bergstrand, J.H. (1989). The generalized gravity equation, monopolistic competition, and the factor proportion theory in international trade. Review of Economics and Statistics, 18(2), 143-53.

Braha, K., Qineti, A., Cupák, A., \& Lazoráková, E. (2017). Determinants of Albanian agricultural export: The gravity model approach. AGRIS On-line Papers in Economics and Informatics, 9(2), 2-3.

Daluwatte, D. \& Sivakumar, S.S. (2018). Economic loss of fisheries due to the postharvest quality loss and assessment of the quality loss in fish. Global Scientific Journal, 6(9), 115-124.

Ehrich, M., \& Mangelsdorf, A. (2018). The role of private standards for manufactured food exports from developing countries. World Development, 101(1), 16-27.

European Union (2018). EU GSP+ business guide for Sri Lankan exporter, www.intracen.org/uploadedFiles/ intracenorg/Content/Redesign/Projects/EU-SRI_LANKA/GSP Business Guide English_Final VERSION. pdf

Fatema, F., \& Islam, M. M. (2020). Driving forces of marine fisheries and seafood export of Bangladesh: Augmented gravity model approach. Asian Journal of Economic Modelling, 8(2), 106-122.

F.A.O. (2004). Processed food for improved livelihoods. FAO publication, Rome.

F.A.O. (2018). The State of World Fisheries and Aquaculture 2018 - Meeting the Sustainable Development Goals. Rome.

F.A.O. (2019). Globefish highlights, Quarterly Update Report of World Seafood, Rome.

F.G., \& Lamonaca, E. (2019). The effects of non-tariff measures on agri-food trade: A review and meta-analysis of empirical evidence. Journal of Agricultural Economics, 70(3), 595-617.

Food and agriculture organization of the United Nations. (2008). Present and future markets for fish and fish products from small-scale fisheries - case studies from Asia, Africa and Latin America. FAO fisheries circular no. 1033, Rome, 89-94.

Fugazza, M. (2017). Fish trade and policy: a primer on non-tariff measures. UNCTAD Research Paper No. 7. UNCTAD/SER.RP/2017/7. Geneva, Switzerland, UN.

Head, K., \& Mayer, T. (2014). Gravity equations: Workhorse, toolkit, and cookbook. Handbook of international economics, 4(1), 131-195.

Levin, L., Lin, C.F., \& Chu, C.H.J. (2002). Unit root tests in panel data: asymptotic and finite-sample properties. Journal of Econometrics, 108, 1-24.

Linders, G.J.M. \& De Groot, H.L.F. (2006). Estimation of the gravity equation in the presence of zero flow. Tinbergen Institute Discussion Paper. TI 2006-072/3.

Noble, S. (2017). Seafood processing industry report 2016. Sea-Fish Economics. Edinburgh, UK . Available at, file://C:/Users/User/Downloads/ 2016\%20Seafood\%20 Processing\%20Industry\%20Report.pdf

Maurseth, P. B., \& Medin, H. (2017). Market-specific sunk export costs: The impact of learning and spillovers. The World Economy, 40(6), 1105-1127.

Melchior, A. (2006), Tariffs in world seafood trade. FAO Fisheries Circular No. 1016, Rome 112- 145.

Murugan, K., \& Sivagnanam, K. J. (2018). Fisheries sector and economic growth in India. Journal of Economic \& Social Development, 14(2), 83-89. 
Natale, F., Borrello, A. \& Motova, A. (2015). Analysis of the determinants of international seafood trade using a gravity model. Marine policy, 60(1), 98-106, doi.org/10.1016/j.marpol.2015.05.016

Rahapakse, P., \&Arunatilake, N. (1997). Would a reduction in trade barriers promote intra-SAARC trade?: A Sri Lankan perspective. Journal of Asian Economics, 8(1), 95-115.

Rindayati, W., \& Kristriana, O. W. (2018). Impact analysis of non-tariff measures (ntm) on Indonesian tuna exports to major destination countries. Journal Management \& Agribusiness, 15(2), 172.

Sandaruwan, K.P.G.L. \&Weerasooriya, S.A. (2019): Non-tariff measures and sustainable development: The case of the European Union import ban on seafood from Sri Lanka. ARTNeT Working Paper Series, No. 185, Asia-Pacific Research and Training Network on Trade (ARTNeT), Bangkok

Sandaruwan, K. P. G. L., Weerasooriya, S. A., Weerahewa, J. (2020). Effects of non-tariff measures on seafood exports from Sri Lanka: A gravity approach. Tropical Agricultural Research , 31(3), 11-24. Santeramo.

Sharif, M. K., \& Zahid, A. (2018). Role of food product development in increased food consumption and value addition. In Food Processing for Increased Quality and Consumption (pp. 455-479). Academic Press.

Shamshak, G. L., Anderson, J. L., Asche, F., Garlock, T., \& Love, D. C. (2019). US seafood consumption. Journal of the World Aquaculture Society, 50(4), 715-727.

Silva, S.J. \&Tenreyro, S. (2006). The log of gravity. The Review of Economics and Statistics. 88(1), 641-658.

Silva, S.J. \&Tenreyro, S. (2011). Further simulation evidence on the performance of the Poisson pseudo-maximum likelihood estimator. Economic letters, 112 (2), 220-222

Singh, R. (2015). Different types of food processing techniques in industry and their significance. Research \& reviews: Journal of Food and Dairy Technology, 3(1), 9-20.

Smith L.P., Wen N.S. \&Popkin, B.M. (2013). Trends in US home food preparation and consumption: analysis of national nutrition surveys and time use studies from 1965-1966 to 2007-2008. Nutrition Journal, 12(1), $1-10$.

Thuong, N.T.T. (2017). The effect of Sanitary and Phytosanitary measures on Vietnam's rice exports. EconomiA, 19 (2), 251-265

Timini, J., \& Conesa, M. (2019). Chinese exports and non-tariff measures. Journal of Economic Integration, 34(2), $327-345$.

Tinbergen, J. (1962). Shaping the world economy: Suggestions for an international economic policy. New York.

United Nations Industrial Development Organization (2011). Trade Standards Compliance of Developing Countries? Analysis of EU and US Data 2002-2008. UNIDO Working Paper, Vienna.

UNCTAD (2013). Non-Tariff Measures to Trade: Economic and Policy Issues for Developing Countries. Developing Countries in International Trade Studies, UNCTAD.

United Nations, (2016) Classification by broad economic categories Rev. 5. Divison of statistics, Department of Economics and Social Affairs, New York.

United Nation Trade Statistics, (2017 August 06), Correspondence Tables. Retrieved from https://unstats.un.org/ unsd/trade/classifications/correspondence-tables.asp

Vatcheva, K.P., Lee, M.J., McCormick, B. \&Rahbar, M.H. (2016). Multicollinearity in regression analyses conducted in epidemiologic studies. Epidemiol (6), 227. doi:10.4172/2161-1165.1000227

Wood, J., Wu, J., Li, Y., \& Kim, J. (2017). TBT and SPS impacts on Korean exports to China: Empirical analysis using the PPML method. Asian-Pacific Economic Literature.

Yang, B., Anderson, J. L., \& Asche, F. (2020). Determinants of China's seafood trade patterns. Marine Resource Economics, 35 (2), 97-112.

Zhang, D., \&Tveterås, R. (2019). A fish out of water? Survival of seafood products from developing countries in the EU market. Marine Policy, 103, 50-58. 